Note

\section{Accumulation of Seed Protein Component in Winged Bean (Psophocarpus tetragonolobus) Development}

\author{
Sonoe OchiaI Yanagi, Masami Kato* \\ and Shunpei Uемото** \\ National Food Research Institute, \\ Ministry of Agriculture, Forestry \\ and Fisheries, Kannondai, \\ Yatabe-machi, Tsukuba-gun, \\ Ibaraki 305, Japan \\ * Miyagi Prefectural Agricultural \\ Research Center, Takadate, Natori-shi, \\ Miyagi 981-12, Japan \\ **Faculty of Agriculture, Kyushu University, \\ Hakozaki, Higashi-ku, Fukuoka 812, Japan
}

Received February 28, 1983

In this paper, the process of protein component accumulation during winged bean (Psophocarpus tetragonolobus) seeds development are investigated and demonstrated ultracentrifugally and electrophoretically, taking into consideration of other seed proteins.

Amounts of protein and fat in winged bean seeds are almost the same as those of soybean seeds. ${ }^{1,2)}$ The protein components of winged bean seeds, however, are considerably different from those of soybeans. ${ }^{2 \sim 4)}$ Two large peaks, 2 to $3 \mathrm{~S}$ and 6 to $8 \mathrm{~S}$, are seen in the ultracentrifugal sedimentation diagram of winged bean whole seed extract, and no larger component is detected under various conditions. ${ }^{3)}$ On the other hand, the major protein components of mature soybean seeds are a $7 \mathrm{~S}$ globulin and an $11 \mathrm{~S}$ globulin at neutral $\mathrm{pH}$ and at an ionic strength near 0.5 . Formation and accumulation of these soybean protein components in developing seeds were investigated previously. ${ }^{5 \sim 7)}$ Meanwhile, the major seed protein component of Phaseolus vulgaris (French bean) is approximately $7 \mathrm{~S}$ at neutral $\mathrm{pH}$, and no $11 \mathrm{~S}$ component is seen, the same as with winged beans. However, a large portion of the 7S component of Phaseolus vulgaris changes into an about $18 \mathrm{~S}$ component at acidic pHs. ${ }^{8)}$

Winged bean variety UPS-99 was cultivated at Kyushu University. UPS 99 is rather photoinsensitive and suitable for cultivation in Japan. ${ }^{9}$ For flowering, it took 60 days (in spring) to 75 days (in autumn) after sowing. The pods with seeds were harvested at $18,26,35,45$, and 55 days after flowering (AF) (Fig. 1). In each collection, seeds of unusual sizes were excluded from the sample. Dry weight was determined by putting freshly weighed seeds at $110^{\circ} \mathrm{C}$, and weighing until the weight bacame constant. Total nitrogen was measured by the micro-Kjeldahl method. ${ }^{10}$ ) Dry weight and the nitrogen percentages of fresh weights rapidly increased from 25 to 30 day AF until maturity. The nitrogen percentages of dry weights also increased gradually from 35 to 55 day AF.

These nitrogen-increasing periods corresponded to the accumulation of seed protein analyzed by ultracentrifugation (Fig. 2). Whole seed protein was extracted with $30 \mathrm{~mm}$ phosphate buffer $\mathrm{pH} 7.5$, including $0.4 \mathrm{M} \mathrm{NaCl}$ and $0.2 \mathrm{~mm}$ dithiothreitol (DTT) by the procedures summarized in Table I. Sedimentation analyses were carried out with a Hitachi ultracentrifuge 282 using a double sector cell and a schlieren optical system at a speed of 56,000

a
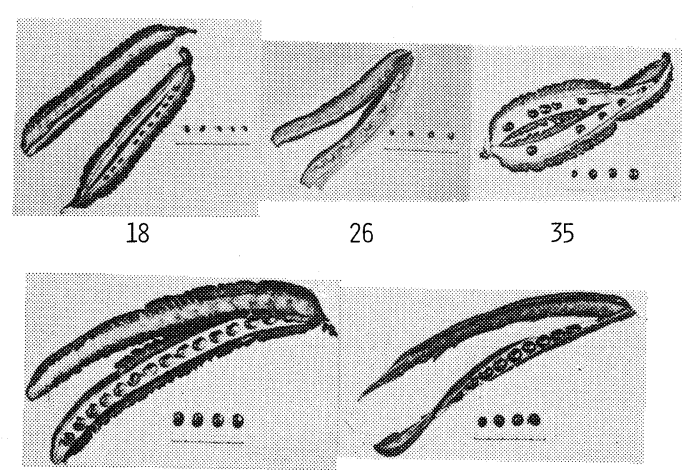

45

55

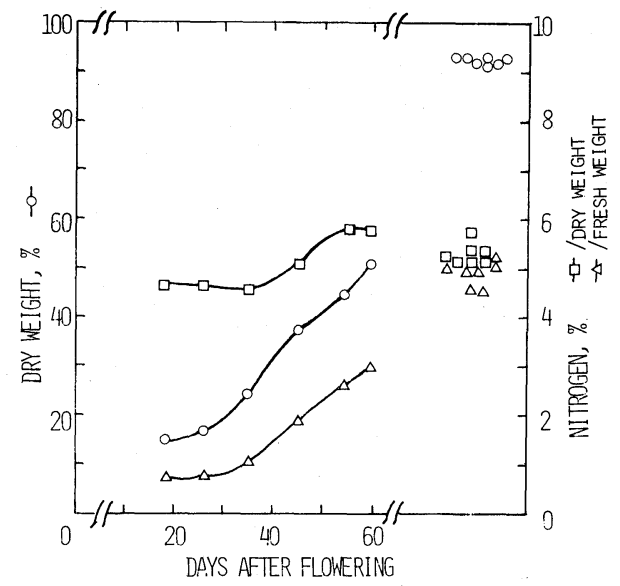

FIG. 1. a: Pictures of Developing Winged Bean Seeds.

The figures represent days after flowering, and one scale section correspond to $1 \mathrm{~cm}$.

b: Dry Weight and Nitrogen Content during Winged Bean Seed Development.

The symbols near the right-hand corners are the results obtained from matured and naturally dried winged bean.

Abbreviations: AF, after flowering, DTT, dithiothreitol, PAGE, polyacrylamide gel electrophoresis 
Table I. Method of Extraction of Developing Winged Bean Seed Protein

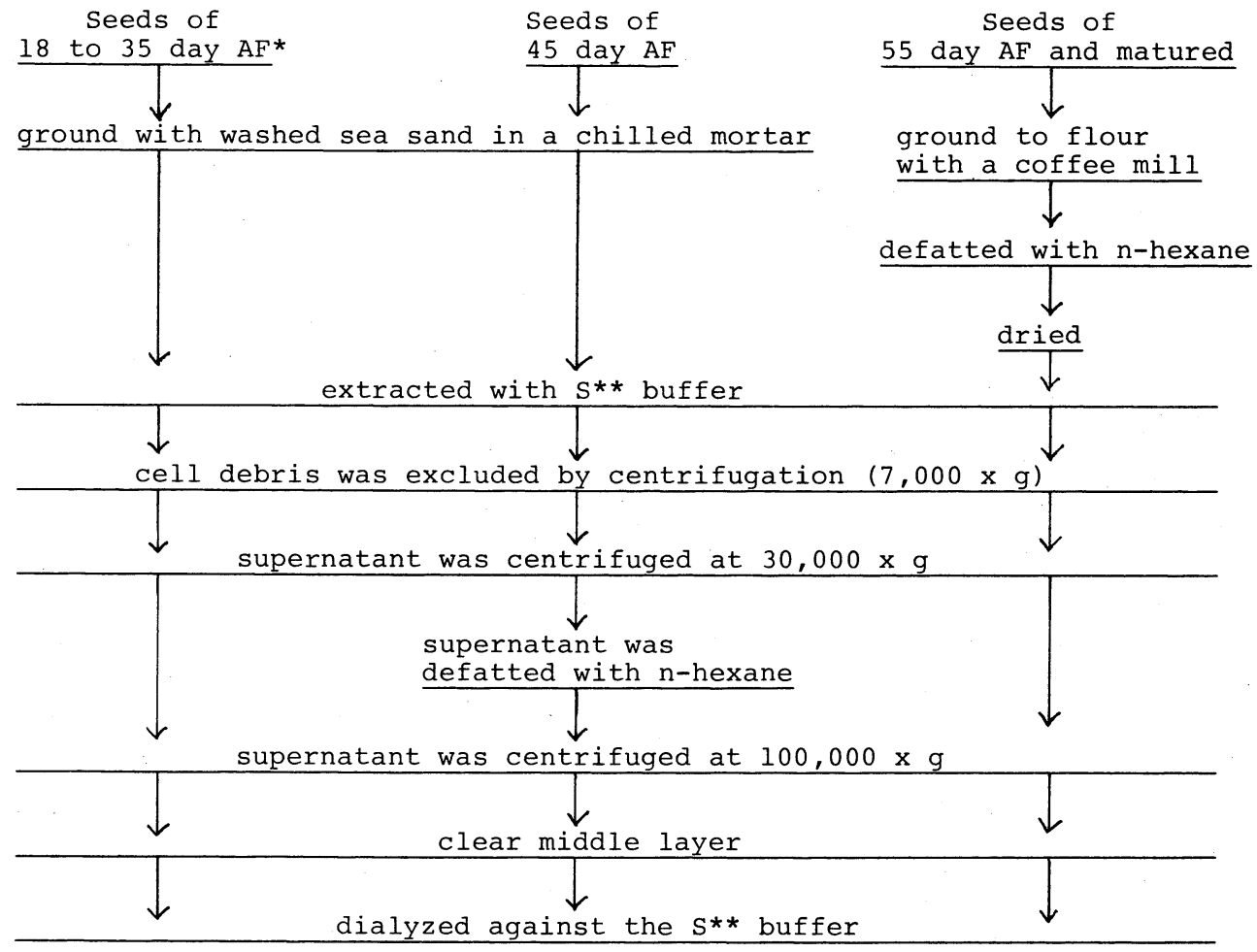

* AF, after flowering.

** $\mathrm{S}$ buffer, $35 \mathrm{~mm}$ potassium phosphate buffer, $\mathrm{pH} 7.5$, containing $0.4 \mathrm{M} \mathrm{NaCl}$ and $0.2 \mathrm{~mm}$ DTT.

$\mathrm{rpm}$ at $20^{\circ} \mathrm{C}$. Six pictures of each run were taken at intervals of $6 \mathrm{~min}$ to calculate Svedberg units. As shown in Fig. 3, only traces of high molecular weight substances were present in the extracts of 18 and 26 days AF. At 35 days AF a broad $3 \mathrm{~S}$ peak appeared, and higher molecular weight components began to be seen at the 45th day AF. The synthesis of the major seed protein component in winged bean seeds seemed to begin at a rather late stage. However, as we pursued the procedure of cultivation of winged beans, an earlier appearance of high molecular weight components was observed. Thus the days after flowering for syntheses of protein components seemed to depend upon various conditions (the season of cultivation, the climate, strains of seeds and so on). The process or the order of synthesis of protein components seemed to be similar at any case, and no particular component which was like the soybean 11S components or the Phaseolus vulgaris $18 \mathrm{~S}$ components was detected, either at $\mathrm{pH} 7.5$ or $\mathrm{pH} 5.2(30 \mathrm{~mm}$ acetate buffer, including $0.4 \mathrm{M} \mathrm{NaCl}$ and $0.2 \mathrm{~mm}$ DTT). The schlieren patterns of whole extract of winged bean seeds in $\mathrm{pH} 7.5$ buffer and in pH 5.2 buffer were fundamentally similar (Fig. 2).

Electrophoretic patterns of the whole seed proteins during winged bean development are shown in Fig. 3.
Polyacrylamide gel electrophoresis (PAGE) was performed mainly by the method of B. J. Davis ${ }^{11)}$ at $\mathrm{pH}$ 8.3. No clear protein band was detected from the extracts of 18 and 26 days AF samples, which seemed to be consistent with the results of ultracentrifuge analyses. As shown by the diagrams from ultracentrifugation, the amount of $6 \sim 8 \mathrm{~S}$ component at 35 days AF was only trace, and after 35 days AF it gradually increased. The electrophoretical patterns of 35 and 45 days AF seemed to be already similar to the 55 day AF or matured stage. However, the band of isolated $6 \sim 8 \mathrm{~S}$ protein component appeared broadly with low mobility and the band of $2 \sim 3 \mathrm{~S}$ proteins appeared as many components, which are shown at the bottom of Fig. 3. Isolation of $2 \sim 3 \mathrm{~S}$ and $6 \sim 8 \mathrm{~S}$ protein by column chromatography is mentioned elsewhere. ${ }^{3)}$ The broad band which corresponds to the $6 \sim 8 \mathrm{~S}$ components at 55 days AF and in the matured sample were clearly thick. This result also seemed to be compatible with the protein patterns of centrifugal analyses.

The protein extract from each sampling stage of development was also analyzed by sodium dodecyl sulfate PAGE. A subunit structure was detectable at 35 days AF and only the relative ratio was changed with maturation (data not shown). 

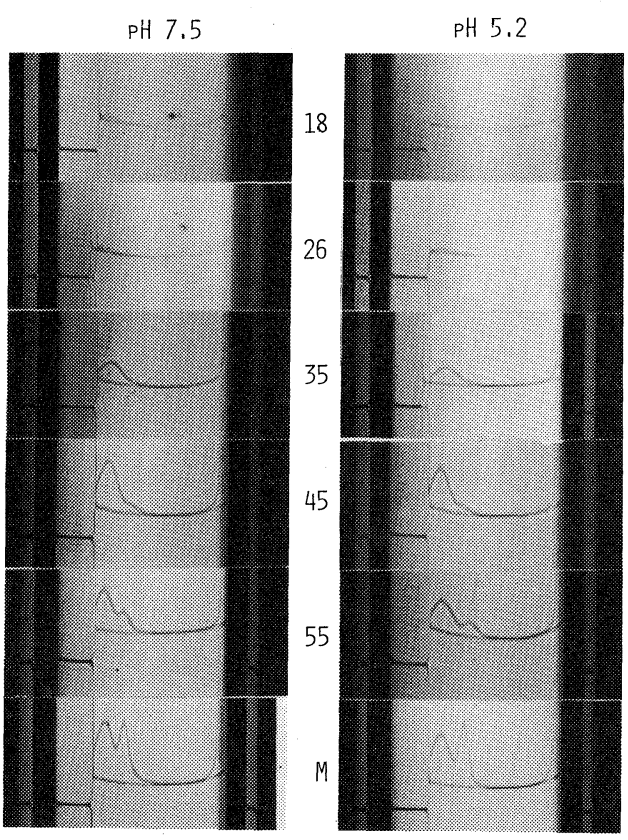

FIG. 2. Ultracentrifuge Sedimentation Diagrams of Winged Bean Whole Seed Extracts during Development. Analyses were carried out in $35 \mathrm{~mm}$ phosphate buffer, $\mathrm{pH}$ 7.5 , or $30 \mathrm{~mm}$ acetate buffer, $\mathrm{pH} 5.2$, containing $0.4 \mathrm{M} \mathrm{NaCl}$ and $0.2 \mathrm{~mm}$ DTT. The schlieren patterns were taken at $30 \mathrm{~min}$ after reaching the speed of $56,000 \mathrm{rpm}$ at $20^{\circ} \mathrm{C}$. The figures are days after flowering.

In conclusion small molecular weight $\mathrm{N}$-components which could be dialyzed out (Fig. 3) were accumulated at the initial stage, a broad peak of rather small $S$ value components appeared next, and $6 \sim 8 \mathrm{~S}$ components were accumulated considerably at late stages of maturation. The course of seed protein synthesis during winged bean maturation, which was similar to those of soybean ${ }^{5)}$ and French bean, ${ }^{12)}$ was demonstrated distinctly by ultracentrifugation and PAGE. It seemed to suggest that these legume storage protein genes might be expressed or controlled generally by similar mechanisms.

\section{REFERENCES}

1) A. Claydon, "The Winged Bean," Philippine Council for Agriculture and Resources Research, 1978, p. 263.

2) S. O. Yanagi, N. Yoshida and K. Saio, Agric. Biol. Chem., 47, 2267 (1983).

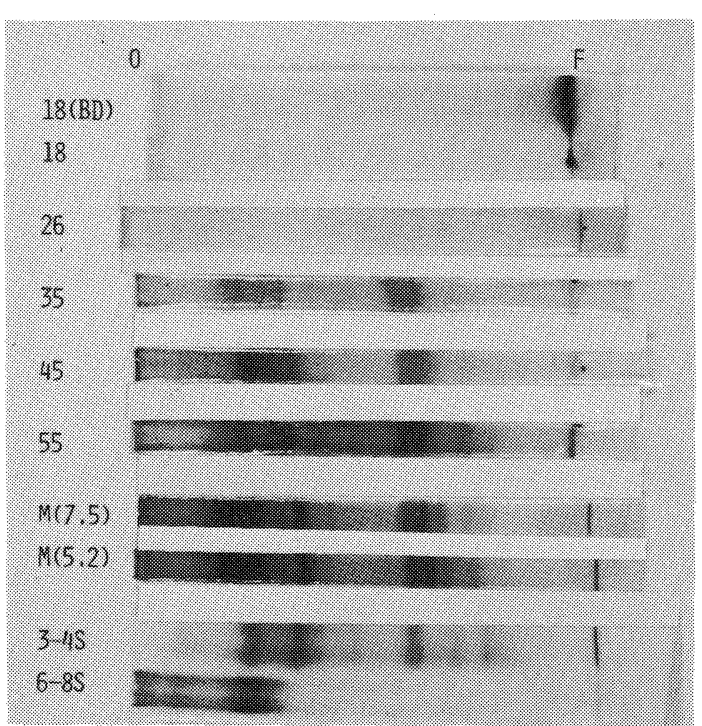

FIG. 3. Polyacrylamide Gel Electrophoresis of Developing Winged Bean Seed Whole Extract.

The method mainly followed was Davis's ( $\mathrm{pH} 8.3$ ) system. ${ }^{11)} \mathrm{O}$ and $\mathrm{F}$ represent origin and front, respectively. Numbers 18 to 55 are the days after flowering, and BD is before dialysis. $\mathbf{M}$ (7.5) and $\mathbf{M}$ (5.2) are the samples extracted from matured seeds with $\mathrm{pH} 7.5$ and $\mathrm{pH} 5.2$ systems, respectively.

3) S. O. Yanagi, Agric. Biol. Chem., 47, 2273 (1983).

4) J. M. Gillespie and F. J. Blagrove, Aust. J. Plant Physiol., 5, 357 (1978).

5) S. O. Yanagi, C. Fukazawa and K. Harada, Agric. Biol. Chem., 42, 697 (1978).

6) M. Asano and K. Shibasaki, J. Japan. Soc. of Food Sci. and Technol., 20, 126 (1973).

7) J. E. Hill and R. W. Breidenbach, Plant Physiol., 53, 747. (1974).

8) J. Romero, S. M. Sun, R. C. McLeester, F. A. Bliss and T. C. Hall, Plant Physiol., 56. 776 (1975).

9) S. Uemoto, K. Fujieda, M. Nonaka and Y. Nakamoto, Buill. Inst. Trop. Agr. Kyushu Univ., 5, 59 (1982).

10) R. H. Burris and P. W. Wilson, "Methods in Enzymol," Vol. IV, ed. by S. P. Colowick and N. O. Kaplan, Academic Press Inc., New York, 1957, p. 356.

11) B. J. Davis, Ann. N. Y. Acad. Sci., 121404 (1964).

12) S. M. Sun, M. A. Mutshler, F. A. Bliss and T. C. Hall, Plant Physiol., 61, 918 (1978). 